\title{
Improving soil and water conservation and ecosystem services by sustain- able soil management practices: From a global to an Italian soil partnership
}

\author{
Filiberto Altobelli, ${ }^{1}$ Ronald Vargas, ${ }^{2}$ Giuseppe Corti, ${ }^{3}$ Carmelo Dazzi, ${ }^{4}$ Luca Montanarella, ${ }^{5}$ \\ Alessandro Monteleone, ${ }^{1}$ Lucrezia Caon, ${ }^{2}$ Maria Grazia Piazza, ${ }^{6}$ Costanza Calzolari, ${ }^{7}$ \\ Michele Munafò, ${ }^{8}$ Anna Benedetti ${ }^{1}$
}

${ }^{1}$ CREA Research Centre for Agricultural Policies and Bioeconomy, Rome; ${ }^{2}$ Land and Water Division, Food and Agriculture Organization of the United Nations (FAO), Rome; ${ }^{3}$ Department of Agricultural, Food and Environmental Sciences, Università Politecnica delle Marche, Ancona; ${ }^{4}$ Department of Agricultural, Food and Forest Sciences, University of Palermo; ${ }^{5}$ European Commission, Joint Research Centre (JRC), Ispra (VA); ${ }^{6}$ CREA Council for Agricultural Research and Analysis of Agricultural Economics, Rome; ${ }^{7}$ CNR Institute for BioEconomy, Sesto Fiorentino (FI); ${ }^{8}$ Italian Institute for Environmental Protection and Research (ISPRA), Rome, Italy

\begin{abstract}
The UN Sustainable Development Goals (SDGs) identify the need to restore degraded soils in order to improve productivity and the provision of ecosystem services. The aim is to support food production, store and supply clean water, conserve biodiversity, sequester carbon, and improve soil resilience in a context of climate change. Within this framework, in order to achieve the SDGs and to correct land management in the long-term, soil management is considered mandatory. The reduction of land degradation should be based on various sustainable soil management practices that improve and maintain soil organic matter levels, increase water infiltration, and improve soil water management. This technical review - a policy paper - summarizes the sustainable and territorial impact of soil degradation, including soil water erosion, from the global level to the European and National levels. Furthermore, with the aim of sharing ongoing soil and water management actions, instruments, and initiatives, we provide information on soil and water conservation activities and prospects in Italy.
\end{abstract}

Correspondence: Filiberto Altobelli, CREA Research Centre for Agricultural Policies and Bioeconomy, Via Po 14, 00198 Rome, Italy Tel.: +39.06.47856568.

E-mail: filiberto.altobelli@crea.gov.it

Key words: Land degradation; soil erosion; water conservation; increase soil availability; soil sealing; sustainable soil management.

Received for publication: 29 October 2020.

Accepted for publication: 3 November 2020.

${ }^{\circ}$ Copyright: the Author(s), 2020

Licensee PAGEPress, Italy

Italian Journal of Agronomy 2020; 15:1765

doi:10.4081/ija.2020.1765

This article is distributed under the terms of the Creative Commons Attribution Noncommercial License (by-nc 4.0) which permits any noncommercial use, distribution, and reproduction in any medium, provided the original author(s) and source are credited.

\section{Introduction}

With the World's population expected to reach $\approx 10$ billion by 2050 (UN, 2019), and considering that $\approx 99 \%$ of the calories needed by humankind comes from the land, more sustainable ways to produce food are required (UN, 2019). Preserving the world foodsupply depends both on the productivity and quality of agricultural soils, which could produce up to $58 \%$ more food than nowadays (FAO, 2015, 2019a; UN, 2019). The United Nations Sustainable Development Goals (SDGs) identify the need to restore degraded soils to improve productivity. To achieve this goal, proper longterm land management is considered mandatory (Keesstra et al., 2016). There is a wide consensus on the need to enhance soil resources to support food production, store and provide clean water, conserve biodiversity, sequester carbon, and improve resilience in a context of climate change (Keesstra et al., 2016). These objectives serve to implement sustainable soil management practices worldwide. Nevertheless, recent FAO data on the Status of the World Soil Resource (2015) indicate that about 33\% of the World's soils are moderately or severely degraded due to unsustainable management practices and other chemical and physical issues mainly related to soil erosion, salinization, compaction, acidification, and chemical pollution. Sustainable soil management (SSM) has been shown to contribute to increase agri-food production, improving the nutritional quality of food and enabling soils to gradually mitigate and adapt to climate change. In particular, 'diverse farming approaches aim to promote the sustainable management of soils with the goal of improving productivity, as well as agroecology, conservation agriculture, agroforestry' (FAO, 2015). The adoption of SSM practices is a valuable tool for adapting to climate change and for embarking on a process of safeguarding key ecosystem services and biodiversity (Garbach et al., 2017; Altobelli and Del Giudice, 2017).

\section{Soil degradation}

SSM practices should be implemented to address soil degradation, which is a degenerative and often irreversible process responsible for the reduction of soil fertility through the modification of its physical, chemical, and biological properties (OECD, 2001). Extensive soil degradation processes have occurred in the European Union in the past and have been increasing rapidly in recent years. In 2011, the European Commission recognized soil sealing, soil erosion, and organic matter decline as the soil degra- 
dation processes on which Member States should concentrate their main efforts, given them economic and environmental relevance (Montanarella, 2007; European Commission, 2011; Costantini and Lorenzetti, 2013). Limiting soil degradation should be based on a variety of sustainable soil management practices, including improving and maintaining soil organic matter levels, increasing infiltration and water conservation, and reducing water extraction and losses (Smith and Powlson, 2007). A good soil management strategy should also contribute to minimizing soil physical and chemical degradation processes, as well as soil salinization, alkalinisation, desertification, and erosion.

\section{Water conservation}

Climate change will increase the variability of water resources availability and induce an increasing water demand for irrigated agricultural systems (Ventrella et al., 2012; Jiménez Cisneros et al., 2014; Altobelli and Del Giudice, 2017). The global value of total crop water used for growing crops is estimated to be 6685 $\mathrm{km}^{3}$ year ${ }^{-1}$, with $800-1100 \mathrm{~km}^{3}$ year ${ }^{-1}$ supplied by rivers, lakes, reservoirs, and groundwater (Siebert and Döll, 2010; Döll et al., 2014). Increasing the efficiency of water use in all economic sectors is a challenge (SDG 6; Target 6.4). In particular, the provision of water for crops is of global significance and increasing the efficiency of this water is a major challenge (Montanarella, 2007). Protecting and improving the physical and chemical characteristics of soils can contribute to store and supply water to plants, thus favouring better use of rainwater.

\section{Soil erosion and soil sealing}

Soil erosion, one of the main drivers of land degradation, is studied by different disciplines and from different perspectives. It has been estimated that the impact of erosion on crop production reduces global crop yields by $0.4 \%$ per year (FAO, 2019b), with a huge economic impact. The European Environment Agency (EEA) estimates that 115 million ha, or 12\% of Europe's total land area, are affected by water erosion (JRC, 2011; Panagos et al., 2014). The main effects of erosion on crop growth are due to the loss of the fertile topsoil layer and the reduction of the rooting area (Van Oost and Bakker, 2012). In order to minimize and reduce large water erosion events on slopes and relatively steep lands, sustainable soil management practices capable of reducing runoff should be applied. In this context, specific cropping and farming systems such as agroforestry, strip cropping, crop rotation, intercropping, contour planting, cross slope barriers, terrace construction and maintenance, and vegetated buffer strips should be adopted (FAO, 2019b). The Thematic Strategy for Soil Protection and its Accompanying document (European Commission, 2006a, 2006b) stressed the assessment of the impact of soil degradation in Europe, amounting to 38 billion euro year ${ }^{-1}$. The most relevant costs are due to erosion (0.7-14.0 billion euro), organic matter decline (3.4-5.6 billion euro), salinisation (158-321 million euro), landslides (up to 1.2 billion euro per event), contamination (2.417.3 billion euro). In Italy, the direct costs of the hydrogeological instability of the last ten years caused by landslides, floods, and soil erosion are estimated to be 9 billion euro (ISPRA, 2013), and the impact of soil sealing since 2012 on soil ecosystem services could lead to 3 billion euro of additional indirect costs per year (Munafò, 2020).

According to Juerges and Hansjürgens (2018), soil governance issues, i.e. 'the sum of all formal and informal institutions (including legal prescriptions, regulation, market incentives, rules, norms, habits and attitudes) that concern the soil related decision- making processes of governmental and non-governmental actors at all levels', are the most significant obstacles to the adoption of measures to control land degradation, including soil erosion. Soil governance therefore depends primarily on voluntary contributions from farmers to manage their soils in a sustainable manner (FAO and ITPS, 2015).

In terms of policy action at the global level, the main instruments for establishing and disseminating soil policies are the United Nations Convention to Combat Desertification (UNCCD) and the Global Soil Partnership (GSP). The GSP is a voluntary instrument responsible for several non-binding instruments such as the Revised World Soil Charter (FAO, 2015), the Voluntary Guidelines for Sustainable Soil Management (VGSSM) (FAO, 2017a) and the International Code of Conduct for the Sustainable Use and Management of Fertilizers (Fertilizer Code) (FAO, 2019c). At the regional level, the most well-established governance instrument is the Soil Thematic Strategy of the European Union, which has coordinated soil related policies across the European Union (European Commission, 2006a).

Soil protection is a very important topic in the European Commission's proposal for the CAP 2021-2027. Strengthening what already foreseen in the past programming period the EC considers Sustainable Soil Management a key element for the achievement of both environmental objectives and those aimed at making European agriculture competitive in the global context. Several instruments are proposed between first and second pillar. More sustainable production techniques of farmers can be supported through eco-schemes or new and more ambitious agri-environmental measures (Monteleone and Marandola, 2018).

\section{Aim of the paper}

The aim of this paper is to explore the main challenges, progresses, and opportunities for a common sustainable soil management, from the global to the European regional level, including Italy. After an overview of the GSP and the Italian Soil Partnership, the opportunities to generate political and technical interest through the sustainable management of national soil resources and through the Italian Soil Partnership will be explored, stressing that the VGSSM is the best example of the technical-policy interaction. Finally, emerging issues within a sustainable soil management framework will be critically examined and discussed.

\section{The Global Soil Partnership}

In the 1990s, the UNCCD, the United Nations Convention on Climate Change (UNFCCC) and the Convention on Biological Diversity (CBD) were established to tackle pressing environmental issues and to pave the way for sustainable development. However, the preservation and sustainable management of soil resources has been overlooked, with the result that the soil issue has gone unnoticed even in the course of the millennium.

With the creation of the GSP at FAO (2012), the United Nations recognized the key role of soils for the Earth, including its particular soil ecosystem services and the provision of healthy and nutritious food. In order to achieve its goals, the GSP organized its work around five Pillars of Actions (Figure 1). These pillars are: to promote sustainable management of soil resources (Pillar 1); to improve the awareness on the soil functions so to encourage investments in terms of education and technical cooperation and to impact on policies (Pillar 2); to encourage research activities and technical skills focusing on the identified knowledge gaps and on 
priorities (Pillar 3); to enhance soil data availability in terms of quality and quantity (Pillar 4); to guarantee the comparability of data and indicators (Pillar 5).

The Plenary Assembly - the highest decision-making body of the Partnership - annually reviews and prioritizes the GSP actions while facilitating a balanced regional decision-making process. The Intergovernmental Technical Panel on Soil (ITPS), composed of 27 soil experts from all regions of the World, provides the GSP with scientific and technical advice and guidance on global soil issues (FAO, 2020).

In 2015, GSP and ITPS published the Revised World Soil Charter (FAO, 2015), an update of the FAO Soil Charter dated from 1981 (FAO, 1981). A participatory process was followed to write and endorse the revised World Soil Charter, which was also applied to the elaboration and publication of other policy-relevant documents: the Status of the World's Soil Resources (FAO and ITPS, 2015), the VGSSM (FAO, 2017a), and the Fertilizer Code (FAO, 2019b).

The VGSSM elaborates the principles outlined in the new version of the World Soil Charter and refers to the risks of soil degradation collected in the report on Soil Resource in the World. The VGSSM presents generally accepted, practically proven, and scientifically based principles to promote SSM and to provide guidance to stakeholders on how to put the principles into practice. The Fertilizer Code (FAO, 2019c) provides a locally adaptable framework and a set of voluntary practices to serve the different stakeholders who are directly or indirectly involved with fertilizers. At present, the GSP is supporting countries and regions to implement these documents. Significant investments have been made in awareness-raising and writing of policy briefs and fact-sheets. In order to promote the endorsement and revision of national soil policies, frameworks, and regulations, the GSP is also establishing SoiLEX (FAO, 2020), an online platform for compiling and sharing policy information. The organization of annual global symposia on specific soil threats, such as the Global Symposium on Soil Organic Carbon (GSOC) in 2017, the Global Symposium on Soil Pollution (GSOP) in 2018, and the Global Symposium on Soil Erosion (GSER) in 2019, has also paved the way for the launch of new policy activities. As reported in Figure 1, the GSP relies on the Regional Soil Partnerships (RSP) to learn about regional needs and priorities and to facilitate the implementation of the GSP actions (Figure 2). The European Soil Partnership (ESP) was established in October 2013 with the aim of bringing soil-related networks and activities under a common framework focusing on three main topics: i) the economic evaluation of the ecosystem services provided by the soil; ii) the development of soil awareness after 2015, declared by the UN as the International Year of Soil; iii) reporting on the state of soil resources in the framework of the Status of the World's Soil Resources Report.

The ESP activities are implemented through a regional Implementation Plan (IP) structured according to the five GSP Pillars. There are various networks in Europe working on soil-related topics that could be involved in the development of the ESP. Among these networks, there is the European Network on Soil Awareness (ENSA); the European Geosciences Union (EGU), Division on Soil System Sciences (SSS); the European Confederation of Soil Science Societies (ECSSS, with the EUROSOIL International Congresses); national soil science societies like the Italian Society of Soil Science (SISS); the EIONET National Reference Centres on Soils of the EEA; the European Soil Data Centre (ESDAC), operated by the European Commission (JRC); the European Soil Bureau Network (ESBN); other European research networks such as the European Joint Programme on cli- mate-smart sustainable management of agricultural soil (EJP Soil). Given the size of the European region and the diversity of soils and historical backgrounds, a number of sub-regional soil partnerships have emerged as an effective way to implement SSM. For example, the Eurasian Sub-Regional Soil Partnership federates the countries of the former Soviet Union and Turkey, while the Alpine Soil Partnership facilitates the implementation of SSM in the Alpine

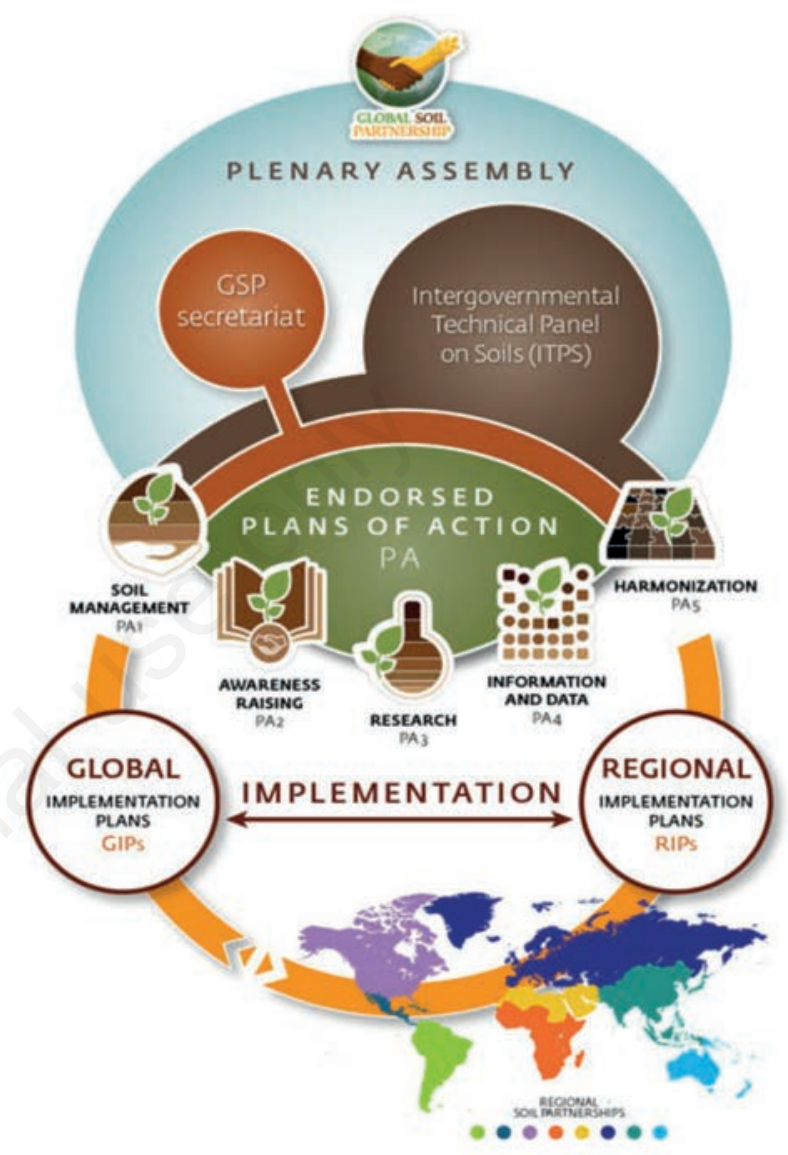

Figure 1. Global Soil Partnership Structure (FAO, 2020).

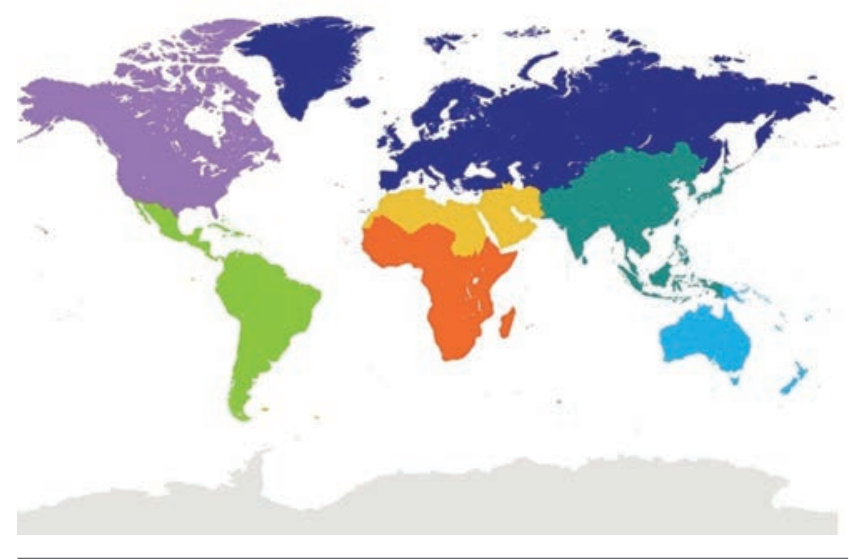

Figure 2. The seven Regional Soil Partnerships (RSP) (FAO, 2020). 
region, mainly supporting the Soil Protocol of the Alpine Convention. Other sub-regional soil partnerships may emerge in the near future as coherent approaches to SSM emerge within the European Union and the EEA member countries.

\section{The Italian Soil Partnership}

The Italian Ministry of Agricultural, Food, and Forestry Policies (MIPAAF) has joined the GSP since its establishment in 2015. The National Focal Point (NFP) for Italy was appointed by the Italian Permanent Representation to the FAO on the recommendation of the Ministry. Since then, in order to participate to the activities planned by the GSP, collaboration has begun among different national institutions. An Italian working group organized in the framework of the ESP and therefore called Italian Soil Partnership (https://scienzadelsuolo.org/GSP.php) collaborates in the ESP activities. Similarly to the GSP and the ESP, the Italian Soil Partnership (ISP) has a voluntary nature and aims mainly at networking ongoing and future soil-related initiatives.

In 2016, the NFP organized a first meeting together with Mipaaf and the Permanent Representation of Italy in Rome. The main scientific societies dealing with soils were also involved, in order to mobilize all the expertise in this field. Currently, the network includes public institutions, research institutions, universities, and farmers. The activities have been framed within the 5 Pillars, and the coordinators of the five Pillars have been identified.

Under the umbrella of the ISP, many activities were carried following the discussions on the results of the GSP and the ESP. Under Pillar 1, the main efforts were devoted to the dissemination of the VGSSM at the national level. These have recently been translated in Italian (FAO, 2017b), as part of the EU-funded LIFE project 'Soil4Life' (www.soil4life.eu), in which several ISP partners are involved. Under Pillar 2, several dissemination activities have been undertaken, including the celebration of World Soil Days. A Decalogue on Soil, with the declination of 10 rules to protect the soil, has been published in collaboration with the Italian Society of Soil Science (SISS), the Italian Society of Pedology (SIPe), the Italian Environmental Fund (FAI), and the National Academy of Agriculture (ANA). For Pillars 4 and 5, a large effort has been made to respond to the GSP request aimed to provide the national soil organic carbon stock map as a contribution to the Global Soil Organic Carbon (GSOC) stock map (FAO and ITPS,
2018; Yigini et al., 2018). The activity of providing the GSOC map for Italy has strengthened the network between bodies and institutions dealing with soil data and information. In fact, much of the soil information is collected and maintained at regional level, which implies that an effort is also needed to define operational procedures and rules for data harmonization and sharing.

\section{The Voluntary Guidelines for Sustainable Soil Management}

SSM can make a significant contribution to facilitating measures to combat desertification, promote biodiversity, and combat climate change through targeted mitigation and adaptation strategies and actions. Consequently, SSM is a central priority for the UNCCD, the $\mathrm{CBD}$, and the UNFCCC. These conventions directly and indirectly provide for the integration of sustainable soil management principles and practices into national policy decisions. The GSP, aware of these needs, has fostered the development of the VGSSM to promote awareness and sustainable soil management at all levels, from regional to global. More specifically, VGSSM are: i) to present universally accepted, positively implemented, and scientifically based principles; and ii) to promote sustainable soil management. They provide tools for 'practical application to all stakeholders in the field of agriculture, pastoralism, forestry, and the management of natural resources' (FAO, 2017a). The VGSSM defines SSM as 'Soil management is sustainable if the supporting, provisioning, regulating, and cultural services provided by soil are maintained or enhanced without significantly impairing either the soil functions that enable those services or biodiversity. The balance between the supporting and provisioning services for plant production and the regulating services the soil provides for water quality and availability and for atmospheric greenhouse gas composition is a particular concern' (FAO, 2015, 2017a).

Ecosystem services are categorized by the Millennium Ecosystem Assessment, the Economics and Ecosystems and Biodiversity, and the Common International Classification Services (M.E.A, 2005; Ring et al., 2010; Haines-Young and Potschin, 2011) into: i) provisional services, including food, biomass (nutrition, animal and plant materials for agriculture use) freshwater, water (for nutrition, drinking and other purposes), genetic resources; ii) regulating and supporting services (air quality and gas regulation, mediation of gas and air flows); iii) regulat-

Table 1. Topics considered in the Voluntary Guidelines for Sustainable Soil Management formulated by the Global Soil Partnership.

\section{The Voluntary Guidelines for Sustainable Soil Management}

1. Minimal rates of soil erosion by water and wind.

2. The soil structure is not degraded (e.g., soil compaction) and provides a stable physical context for movement of air, water, and heat, as well as root growth.

3. Sufficient surface cover (e.g. from growing plants, plant residues, etc.) is present to protect the soil.

4. The store of soil organic matter is stable or increasing and ideally close to the optimal level for the local environment.

5. Availability and flows of nutrients are appropriate to maintain or improve soil fertility and productivity, and to reduce their losses to the environment.

6. Soil salinization, sodification and alkalinization are minimal.

7. Water (e.g. from precipitation and supplementary water sources such as irrigation) is efficiently infiltrated and stored to meet the requirements of plants and ensure the drainage of any excess.

8. Contaminants are below toxic levels, i.e. those which would cause harm to plants, animals, humans and the environment.

9. Soil biodiversity provides a full range of biological functions.

10. The soil management systems for producing food, feed, fuel, timber, and fibre rely on optimized and safe use of inputs.

11. Soil sealing is minimized through responsible land use planning. 
ing services, including water purification and treatment, waste treatment (water purification); mediation of waste, toxic substances and other nuisances by biota and ecosystem; iv) regulating and maintenance services (water regulation, erosion regulation, climate regulation, pollination, pest and disease regulation, primary production, nutrient cycling, erosion prevention, biological control, soil formation and composition, maintenance of water condition); v) cultural and amenity services, including recreation and ecotourism, knowledge system, and educational values. SSM is associated with these characteristics, as reported in Table 1.

The VGSSM emphasizes the role of some important SSM practices, such as the use of cover crops or the distribution of organic and/or non-organic residues to protect the soil surface against erosion (FAO, 2017a). Moreover, the enhancement of soil organic matter (SOM) content is one of the main drivers in maintaining soil functions and preventing soil degradation processing. SOM is of strategic importance for climate change adaptation and mitigation, as soil is the largest pool of organic carbon and plays an important role in regulating climate change. SSM practices such as cover crops can improve crop production and reduce tillage practices and should be adopted to ensure that the soil has sufficient organic cover.

Improving soil water management, especially in Mediterranean dryland cropping systems, should be implemented to optimize water use efficiency, through practices such as: i) soil cover management, in this case the shifting and relocation of crops and cropping systems can be an option for crop management (Jovanovic et al., 2020); and ii) water harvesting, including all water harvesting techniques for agriculture as capturing and storing water in dams, reservoirs, as well as increasing water in the soil to increase soil water availability at sowing (Oweis et al., 2012). The reduction of runoff and evaporation losses from the soil surface are not less important since they ensure an adequate water availability at each stage of crop development. Thus, appropriate cultivars should be promoted and the timing of agronomic operation should be carefully chosen (Jovanovic et al., 2020).

Minimizing soil sealing is another major challenge to preserve the soil from degradation processes. Soil sealing refers to covering the ground by an impermeable surface (Langella et al., 2020). The natural sealing is commonly followed by transport and deposition of detached particles (Panini et al., 1997; Singer and Shainberg, 2004; Singer, 2006). Soil waterproofing can be defined by various natural causes such as loss of structure due to the impact of rain on the soil surface, or poorly managed tillage which is responsible for soil compaction. In contrast to natural sealing, artificial sealing is generally extensive and rather permanent, and leads to changes in the neighbouring ecosystems (e.g., Burghardt, 2006; Munafò, 2020). Soil sealing is then a common consequence of urbanization and infrastructure construction (Lo Papa et al., 2013) and, together with changes in land cover, is the cause of a largely irreversible loss of all or part of soil functions and the ecosystem services it provides (FAO, 2017b). Land consumption and soil sealing continue in Europe and Italy, predominantly at the expense of agricultural land, reducing its productive potential. The annual rate of soil sealing in Europe was $334 \mathrm{~km}^{2}$ between 2012-2015 (EEA, 2019). In order to keep productivity-related soil functions unchanged, all infrastructure policy criteria affecting soil should be carefully considered. Soils with significant ecosystem services, including high agricultural suitability, should be protected from land conversion by special legislation (FAO, 2017b).

\section{Conclusions and recommendations}

The SDGs provide an excellent channel to explain the main issues and the significance of soils (Bouma, 2019). The SDGs identify the need to restore degraded soils in order to improve productivity and correct long-term land management to achieve sustainable use of soil ecosystems services, combat desertification, and improve soil water availability. Soil management supports a number of SDGs, such as sustainable productivity (SDG 2 ensures sustainable food production systems and implements resilient agricultural practices that increase productivity and production, and progressively improves land and soil quality), soil water availability (SDG 6 is related to the withdrawal of freshwater in proportion to the available freshwater resources), carbon capture (SDG 13 contributes to urgent action to combat climate change and its impacts), and soil degradation (SDG 15 combat land degradation, halt biodiversity loss). The choice of appropriate actions to contain soil degradation, water conservation soil erosion within a tolerable range is an essential component of SSM (FAO, 2017b), and VGSSM emphasizes the role of some important SSM practices like use of cover crops, distribution of organic and/or non-organic residues, and water availability (FAO, 2017a).

The role of soil resources in this context has been well recognized by stakeholders and policy makers, including the active role of the GSP, which provides an up-to-date framework for the sustainable use of soil resources, for food security and for climate change adaptation and mitigation. In 2020, the accreditation of the ISP to the GSP will allow Italy participating to various activities at both nationally and internationally level. This interesting activism at global, regional and national level indicates that the time may be ripe to take effective action for soil protection at the Italian level, in the hope this will improve our environment and livelihoods.

\section{Highlights}

- Sustainable soil management practices should be implemented to address soil degradation.

- Impact of erosion on crop production reduces global crop yields by $0.4 \%$ per year.

- Improving the physical and chemical characteristics of soils can contribute to store and supply water to plants.

- Soil protection is a very important topic in the European Commission's proposal for the CAP 2021-2027.

\section{References}

Altobelli F, Del Giudice T, 2017. The economic, social and environmental aspects for healthy soils: Assessment for Sustainable Development. Ital. Rev. Agric. Econ. 72:5-6.

Bouma J, 2019. Soil security in sustainable development. Soil Syst. 3:5. Burghardt W, 2006. Soil Sealing and Soil Properties Related to Sealing. Geological Society, London, UK.

Costantini EA, Lorenzetti R, 2013. Soil degradation processes in the Italian agricultural and forest ecosystems. Ital. J. Agron. 8:e28.

Döll P, Müller Schmied H, Schuh C, Portmann F T, Eicker A, 2014. Global-scale assessment of groundwater depletion and related groundwater abstractions: Combining hydrological modelling with information from well observations and GRACE satellites. Water Resour. Res. 50:5698-720.

European Commission, 2006a. Communication from the Commission to the Council, the European parliament, the European economic and social committee and the committee of the regions. Thematic 
strategy for soil protection. (COM(2006)231 final). European Commission, Brussels, Belgium.

European Commission, 2006b. Accompanying document to the Communication from the Commission to the Council, the European Parliament, the European Economic and Social Committee and the Committee of the Regions - Thematic Strategy for Soil Protection - Summary of the impact assessment.

European Commission, 2011. Communication from the Commission to the Council, the European parliament, the European economic and social committee and the committee of the regions. Roadmap to a Resource Efficient Europe. 20.9.2011. COM (2011) 571 final. European Commission, Brussels, Belgium.

FAO, 1981. World Soil Charter. Available from: http://www.fao.org/3/ a-i4965e.pdf

FAO, 2012. The state of the world's land and water resources for food and agriculture (SOLAW) - Managing systems at risk. Food and Agriculture Organization of the United Nations, Rome and Earthscan, London.

FAO, 2015. Revised World Soil Charter. Available from: http://www. fao.org/soils-portal/policies-governance/en/

FAO, 2017a.Voluntary Guidelines for Sustainable Soil Management (available in Italian). Filiberto Altobelli, Anna Benedetti, Manuela De Pace, Maria Grazia Piazza. FAO - CREA. Available from: http://www.fao.org /publications/card/en/c/I6874IT

FAO, 2017b. Voluntary Guidelines for Sustainable Soil Management. Food and Agriculture Organization of the United Nations Rome, Italy.

FAO, 2019a. FAO Food Balance Sheets. FAOSTAT, Food and Agriculture Organization of the United Nations, 2019. Available from: http://www.fao.org/faostat/en/\#data/FBS Accessed: 28 May 2020.

FAO, 2019b. Soil erosion: the greatest challenge to sustainable soil management. Food and Agriculture Organization of the United Nations, Rome. 100 pp.

FAO, 2019c. The International Code of Conduct for the Sustainable Use and Management of Fertilizers. Food and Agriculture Organization of the United Nations, Rome.

FAO, 2020. The Global Bioenergy Partnership (FAO). Available from: http:/www.fao.org/global-soil-partnership/ resources/ highlights/ detail/en/c/1274929/

FAO, ITPS, 2015. Status of the World's Soil Resources (SWSR) - Main Report. Food and Agriculture Organization of the United Nations and Intergovernmental Technical Panel on Soils. Food and Agriculture Organization of the United Nations, Rome, Italy.

FAO, ITPS, 2018. Global Soil Organic Carbon Map (GSOC map) Technical Report. Food and Agriculture Organization of the United Nations, Rome. 162 pp.

Garbach K, Milder J C, DeClerck F A J, Montenegro de Wit M, Driscoll L, Gemmill-Herren B, 2017. Examining multi-functionality for crop yield and ecosystem services in five systems of agroecological intensification. Int. J. Agric. Sustain. 15:11-28.

Haines-Young R, Potschin M, 2011. Common international classification of ecosystem services (CICES): 2011 Update. Report to the European Environmental Agency, Nottingham, UK.

Jiménez Cisneros BE, Oki T, Arnell NW, Benito G, Cogley JG, Döll P, Jiang T, Mwakalila SS, 2014. Freshwater resources. Climate Change 2014: Impacts, Adaptation, and Vulnerability. Part A: Global and Sectoral Aspects. Contribution of Working Group II to the Fifth Assessment Report of the Intergovernmental Panel on Climate Change.

Jovanovic N, Pereira L S, Paredes P, Pôças I, Cantore V, Todorovic M, 2020. A review of strategies, methods and technologies to reduce non-beneficial consumptive water use on farms considering the
FAO56 methods. Agric. Water Manage. 239:106267.

JRC (Joint Research Centre), 2011. The state of soil in Europe. Publication Office of the European Union, Luxembourg, p 78.

Keesstra SD, Bouma J, Wallinga J, Tittonell P, Smith P, Cerdà A, Montanarella L, Quinton JN, Pachepsky Y, van der Putten WH, Bardgett RD, Moolenaar S, Mol G, Jansen B, Fresco LO, 2016. The significance of soils and soil science towards realization of the United Nations Sustainable Development Goals. Soil 2:111-28.

Langella G, Basile A, Giannecchini S, Moccia FD, Mileti FA, Munafó M, Pinto F, Terribile F, 2020. Soil Monitor: an internet platform to challenge soil sealing in Italy. Land Degrad. Develop. [Epub ahead of print].

Lo Papa G, Palermo V, Dazzi C, 2013. The "genetic erosion" of the soil ecosystem. Int. Soil Water Conserv. Res. 1:11-18.

Montanarella L, 2007. Trends in Land Degradation in Europe. In: M.V.K. Sivakumar, N. Ndiang'ui (Eds.), Climate and Land Degradation. Environmental Science and Engineering (Environmental Science). Springer, Berlin-Heidelberg, Germany.

Monteleone A, Marandola D, 2018. Una nuova architettura verde post 2020. Rete Rurale Nazionale Magazine, n. 4, 2018.

M.E.A. (Millennium Ecosystem Assessment), 2005. Ecosystems and human well-being. Synthesis. Available from: https://www.millenniumassessment.org/documents/document.356.aspx.pdf

Munafò M (Ed.), 2020. Consumo di suolo, dinamiche territoriali e servizi ecosistemici. Edizione 2020. Report SNPA 15/20.

OECD (Organisation for Economic Co-operation and Development), 2001. Environmental indicators for agriculture - vol. 3: Methods and results, glossary, OECD Publ., Paris, France, 2:410.

Oweis TY, Prinz D, Hachum AY, 2012. Water Harvesting for Agriculture in the Dry Areas. CRC Press, Boca Raton, FL, USA.

Panagos P, Meusburger K, Van Liedekerke M, Alewell C, Hiederer R, Montanarella L, 2014. Assessing soil erosion in Europe based on data collected through a European network. Soil Sci. Plant Nutr. 60:15-29.

Panini T, Torri D, Pellegrini S, Pagliai M, Sanchis M P S, 1997. A theoretical approach to soil porosity and sealing development using simulated rainstorms. Catena 31:199-218.

Ring I, Hansjürgens B, Elmqvist T, Wittmer H, Sukhdev P, 2010. Challenges in framing the economics of ecosystems and biodiversity: the TEEB initiative. Curr. Opin. Environ. Sustain. 2:15-26.

Siebert S, Döll P, 2010. Quantifying blue and green virtual water contents in global crop production as well as potential production losses without irrigation. J. Hydrol. 384:198-217.

Singer, 2006. Physical degradation of soils. In: Certini G., Scalenghe R. (Eds.), Soils. Basic Concepts and Future Challenges, Cambridge University Press, Cambridge, UK, pp. 223-232.

Singer MJ, Shainberg I, 2004. Mineral soil surface crusts and wind and water erosion. Earth Surf. Process. Landf. 29:1065-75.

Smith P, Powlson DS, 2007. Sustainability of Soil Management Practices - a Global Perspective. In: L.K. Abbott, D.V. Murphy (Eds.), Soil Biological Fertility. Springer, Dordrecht, pp 241-254.

UN (United Nations), 2017. World population projected to reach 9.8 billion in 2050, and 11.2 billion in 2100. Available from: https://www.un.org/development/desa/en/news/population/worldpopulation-prospects-2017.html

Ventrella D, Giglio L, Charfeddine M, Lopez R, Castellini M, Sollitto D, Castrignanò A, Fornaro F, 2012. Climate change impact on crop rotations of winter durum wheat and tomato in southern Italy: yield analysis and soil fertility. Ital. J. Agron. 7:100-8, e15.

Yigini Y, Olmedo GF, Reiter S, Baritz R, Viatkin K, Vargas R (Eds.), 2018. Soil Organic Carbon Mapping Cookbook, 2nd edition. FAO, Rome, Italy, $220 \mathrm{pp}$. 